\title{
Мал ылаңдарын алдын алуудагы кыргыз элинин салттуу ыкмалары
}

\author{
Гүлназ Аскарбек ${ }^{1 a^{*}}$ Аскарбек Түлөбаев ${ }^{2 b}$
}

${ }^{1}$ Кыргыз-Түрк «Манас» Университети, Коомдук илимдер институту, Тарых билим багыты, Бишкек, Кыргызстан ${ }^{2}$ Кыргыз-Түрк «Манас» Университети, Ветеринария факультети, Ветеринарияга негиз илимдер бөлүмү, Бишкек, Кыргызстан

${ }^{a}$ https://orcid.org/0000-0003-3514-4867, ${ }^{b}$ https://orcid.org/0000-0003-1349-6511

*Корреспондент автор: askarbek.tulobayev@ manas.edu.kg

\section{АННО А ЦИ Я}

Кыргыз эли көптөгөн кылымдарды карыткан бай маданий мураска ээ этнос. Көптөгөн кылымдар бою алар көчмөн мүнөздүү турмуш-тиричилик кечирип жашап келишкен. Бүгүнкү күндөрдө дагы айыл жергелериндеги мал чарбасы менен алектенген калк жарым-жартылай көчмөн турмушта жашап келишет. Этноветеринардык медицинадагы билимдер, усулдар жана практикалар кыргыз элинин көчмөн цивилизациясынын татаал жана дээрлик изилденбеген бөлүгү болуп келет. Башка этникалык тайпалар сыяктуу эле, кыргыз эли дагы өсүмдүк, айбан жана минерал табияттуу өндүрүмдөрдү мал дарыгерликте кеңири пайдаланышып, ар кандай ритуалдарды дагы колдонуп келишкен. Мындай этноветеринардык дары каражаттары негизинен элдик ыкмалар, ишенимдер, билимдер, практикалар жана усулдар менен тыгыз байланышкан. Салттуу билимдерге, ыкмаларга жана усулдарга таянган дары каражаттарын малдын ылаңдарын алдын алууда, малдын дарттарын дарылоодо колдонуу көчмөн кыргыз эли үчүн абдан маанилүү болгон. Кыргыз элинин мал ылаңдарын алдын алуудагы колдонгон каражаттарынын жана ыкмаларынын көпчүлүгү илимий негиздөөгө алынган эмес, ошондуктан бүгүнкү күнгө дейре илимий-врачтык далилдөөгө караганда этнографиялык кызыгууну жаратып келет. Бул макаланын максаты - кыргыз элинин малдын ылаңдарын алдын алууда колдонулган салттуу билимдерин жана ыкмаларын изилдөө болуп саналат. Изилдөөлөрдүн максатына ылайык илим-изилдөө мекемелеринин архивдеринде, илимий китепканаларда иликтөө иштери, Ысык-Көл жана Нарын областарында байкоолор, малчылар жана ветеринардык адистер менен жеке сурамжылоолорго негизделген талаа изилдөөлөрү жүргүзүлдү. Изилдөөлөрдүн жыйынтыгында төмөндөгүдөй маалыматтар алынды: мал баш калкалоочу жайлардын жалпы «санитардык-эпидемиологиялык» тазалыгын камсыздоо иш-чараларынын аткарылышы; жайыттын-конуштун «колдоочуларына» жана малдын «пирлерине» арналган ырым-жырымдар; малды жыландардан, курт-кумурскалардан жана башка мителерден коргоо иш-чаралары; жыл мезгилдерине тиешелүү коркунучтарды алдын алуу иш-чаралары; бооз малды, жаш төлдү жана төлүн эмизген малдын денсоолугун сактоого карата жүргүзүлгөн иш-чаралар; мал ылаңдарын алдын алууда санитардык-гигиеналык ыкмаларды, минералдарды жана дары өсүмдүктөрдү колдонуу; малдын жугушсуз, жугуштуу жана мите ыдаңдарын алдын алуудагы иш-чаралар.
МАКАЛА

\section{М А АЛ Ы М А Т Ы}

Илимий макала

ЖиберуҮ: 22.02.2021

Кабыл алуу: 21.10.2021

Ачкыч сөздөр: Кыргызстан, элдик ветеринария, мал ылаңдарын алдын алуу, салттуу ыкмалар

\section{The Traditional Knowledge of the Kyrgyz People in the Prevention of Animal Diseases}

\section{A B S T R A C T}

The Kyrgyz people have a rich centuries-old cultural heritage. For many centuries, they have led a nomadic lifestyle, and even today, in rural areas, people who are engaged in livestock breeding lead a seminomadic lifestyle. Like other ethnic groups, the Kyrgyz people widely use plant-based, animal-derived and mineral-derived natural products, and engage in various religious rituals. These ethnoveterinary medicines are generally associated with folk skills, beliefs, knowledge, practices, and methods related to animal health in the ethnic group areas. The use of plant species mentioned for ethnoveterinary use in the folk cure and prevention of livestock ailments on the part of the nomadic Kyrgyz people is very important. Most of the tools and methods used by the Kyrgyz people in the prevention of animal diseases are not scientifically substantiated, and to this day are of more ethnographic interest than scientific evidence. The purpose of this research is to study the traditional knowledge and methods used by the Kyrgyz people in the prevention of animal diseases. According to the purpose of the present research, which was conducted in the archives of research institutions, scientific libraries and based on field surveys with herders and veterinarians in Issyk-Kul and Naryn oblasts. As a result of the research, the following information was collected: implementation of measures to ensure general "sanitary and epidemiological" cleanliness of animal shelters; rituals dedicated to "patrons" of pastures and "pir (protectors)" of animals; measures to protect livestock from snakes, insects, and other parasites; prevention measures of seasonal hazards; measures are taken to protect the health of pregnant, young, and lactating animals; use of sanitary and hygienic methods, minerals, and medicinal plants in the prevention of animal diseases; measures for the prevention of non-infectious, contagious and parasitic diseases of animals.
ARTICLE INFO

Research article

Received: 22.02 .2021

Accepted: 21.10 .2021

Keywords:

Kyrgyzstan, folk veterinary medicine, the prevention of animal diseases, traditional knowledge.

To Cite: Аскарбек Г, Түлөбаев А, 2021. Мал ылаңдарын алдын алуудагы кыргыз элинин салттуу ыкмалары. MJAVL Sciences. 11 (2) 138-144 


\section{КИРИШУУ}

Кыргыз эли өзүнүн көп кылымдык турмушунда жашоо-тиричиликке, айлана-чөйрөгө жана чарбалык ишмердүүлүккө тиешелүү бай практикалык билимдерди топтогон. Бул салттуу билимдер жана ыкмалар элибиздин тажырыйбалуу улуу мүчөлөрүнөн жаш муундарга оозеки берилип келген. Бирок салттуу билимдерди жана ыкмаларды жазма булактар түрүндө кийинки муундарга калтыруу көйгөйү ушул күндөргө чейин олуттуу бойдон калууда.

Ветеринария тармагындагы салттуу билимдер жана ыкмалар тууралуу маалыматтар дагы негизинен оозеки жана фольклордук булактар аркылуу жайылтылган (Tulobaev 2001).

Кыргыз элинин ветеринария тармагындагы салттуу билимдерин жана ыкмаларын изилдөөгө жана жайылтууга С.М. Абрамзон, Б. Солтоноев, Т. Баканов, А.А. Алдашев, А.Т. Жунушов, А.З. Түлөбаев авторлоштору менен, М.Б. Айтматов авторлоштору менен, Э.А. Саргашкаев ж.б. өз салымдарын кошушуп, көйгөйдү чечүY максатында эмгектенишкен (Bakanov 1971; Aldashev 1989; Zhunushov 1991; Soltonoyev 1993; Abramzon 1999; Tulobaev 2001; Tulobaev ж.б. 2014; Sargashkayev 2015; Tulobaev жана Salykov 2016; Aytmatov ж.б. 2017; Tulobaev ж.б. 2018).

Көчмөн малчылардын кээ бир жугуштуу ылаңдардын алдын алуу ыкмалары ар тараптуу болуп, кээ бирөөлөру илимий жана практикалык багыттарда кызыгууну туудурат. Мисалы, жылкылардын сакоосу балдардын кызамыгы сыяктуу эле, жаш малдын ылаңы катары бардык кулун-тайлар ылаңдап чыгуусу керек эле. Инфекциянын тез өтүшү үчүн, ылаңдуу кулун-тайлардын жаак астындагы ириңин, мүйүздөн, же сөөктөн жасалган курч бычак менен жарышып, сакоо ириңин дени соо кулун-тайлардын эринине сыйпашып, өздөрү билип-билбей эле, жасалма эмдөө жүргүзүшкөн (Aldashev 1989; Tulobaev ж.б. 2014; Tulobaev жана Salykov 2016).

Кыргыз элинин мал ылаңдарын алдын алуудагы (профилактика) колдонгон каражаттарынын жана ыкмаларынын көпчүлүгү илимий негиздөөгө алынган эмес, ошондуктан бүгүнкү күнгө дейре илимий-врачтык далилдөөгө караганда этнографиялык кызыгууну жаратып келет (Tulobaev ж.б. 2014; Tulobaev жана Salykov 2016).

Бул макаланын максаты - кыргыз элинин көчмөн малчылыгындагы малдын ылаңдарын алдын алууда колдонулган салттуу билимдерин жана ыкмаларын изилдөө, илимий-врачтык талкууга алуу жана аларды Кыргыз Республикасынын жайыт малчылыгында колдонуу мүмкүнчүлүктөрүн аныктоо болуп саналат.

\section{МАТЕРИАЛДАР ЖАНА МЕТОДДОР}

Изилдөөлөрдүн объектиси болуп кыргыз элинин жайыт малчылыгындагы салттуу ветеринария системасы, предмети болуп кыргыз элинин көчмөн малчылыгындагы салттуу ветеринардык билимдери жана ыкмалары саналды.

Изилдөөлөрдүн максатына ылайык илим-изилдөө мекемелеринин архивдеринде, илимий китепканаларда жана интернет булактарында иликтөө иштери, Ысык-Көл жана Нарын областарында талаа изилдөөлөрү жүргүзүлдү.

Талаа изилдөөлөрүнүн ыкмасы түздөн-түз байкоолорго жана жеке сурамжылоолорго негизделди. Сурамжылоолор салттуу билимдерди алып жүрүүчүлөр болгон негизги маалыматчылар (малчылар, ветеринардык адистер) менен жүргүзүлүп, алынган маалыматтар башка респонденттерден мурда-кийин алынган материалдар менен толукталды.

Бул макалага негиз катары илимий булактардагы маалыматтар, талаа изилдөөлөрү учурунда чогултулган этнографиялык, илимий жана практикалык материалдар колдонулду.

\section{иЗИЛДӨӨЛӨРДҮН ЖЫЙЫНТЫГЫ ЖАНА ТАЛКУУЛОО}

Кыргыз элинде мал ылаңдарын алдын алуу максатында аздыр-көптүр ар кандай иш-чаралар жана ырымжырымдар аткарылган. Бул аракеттер төмөндөгү багыттарга бөлүнүп каралды: 1) Мал ылаңдарын алдын алуунун жалпы иш-чаралары жана ырым-жырымдары; 2) Малдын ылаңдарын алдын алуунун жеке ишчаралары жана ырым-жырымдары.

Бизге жеткиликтүу болгон маалыматтар төмөндө келтирилип, талкууга алынды.

Мал ылаңдарын алдын алуунун жалпы иш-чаралары жана ырым-жырымдары.

Мал короонун (таш короонун), мал түнөгүнүн ж.б. мал баш калкалоочу жайлардын жалпы «санитардыкэпидемиологиялык» тазалыгын камсыздоо максатында ал жайларды таштардан, таштандылардан, чыла- 
чалчыктардан тазалашып, арча (Juniperus L., 1753) же адырашман (Peganum harmala L., 1753) түтөтүшүп «аласташкан».

Аластоодо: Алас, алас, ар балээден калас, Жаман көздөн, суук сөздөн сакта. Корообуз малга толсун, Ылаң-сыркоо болбосун - деп, кудайдан тилешкен.

Жогорудагы аткарылган жалпы «санитардык-эпидемиологиялык» иш-чаралар илимий ветеринариянын принциптеринин көпчүлүк жоболоруна (Raimbekov 2010) дал келгендиги менен салттуу ветеринариянын маанисин жогорулатат.

Арчанын мал ылаңдарын алдын алуу максатында салттуу ветеринарияда колдонулушу, анын курамында фитонциддер жана эфир майлары бар экендиги (Mammadova 2015), алардын ар кандай микроорганизмдерге карата антимикробдук таасир көрсөтөөрү (Aliyev ж.б. 1970; Novikov ж.б. 2014) жана алардын бактерициддик жана фунгициддик таасирлери дагы аныкталгандыгы менен далилденген десек жаңылышпайбыз.

Адырашмандын алкалоиддери жана экстрактары антибактериялык, антивирустук жана антипаразиттик касиеттерге ээ экендиги кийин жүргүзүлгөн илимий изилдөөлөрдө аныкталган (Altymyshev 1976; Astulla ж.б. 2008; Nenaah 2010; Moloudizargari ж.б. 2013; Soliman ж.б. 2013; Karomatov 2014; Mina ж.б. 2015; Apostolico ж.б. 2016; Herraiz ж.б. 2017; Li ж.б. 2017).

Жайыт-конуш которуштурууларда жайыттын-конуштун «колдоочуларына» жана малдын «пирлерине» арнап «кан чыгарышып» (улак же козу союшуn) куран, дуба окушкан, шам жагып (чийдин башына кебез ороп, койдун майына малып aлыn), мал короого арча же балыктын сөөгүн күйгүзүп түтөтүшүп, же оттун чогуна сары май, же койдун майын салып түтөтүшүп, 7 же 9 «токоч баабедин» жасашып, мал көбөйсүн, ылаңдабасын деп ырымдашкан.

Мындай ырым-жырымдар элдин тутунган диний көз караштарына жана ишенимдерине байланыштуу аткарылган иш-чаралар болгон (Abramzon 1999).

Айрым учурларда түнкүсүн жыландар, курт-кумурскалар жана башка мителер дагы малдын тынчын алган. Мындай учурларда мал короону (таш короону), же мал түнөгүн, же мал баш калкалоочу жайларды айланта кыл аркан таштап, кескин жыттуу же жыты ачуу эрмен сыяктуу өсүмдүктөрдөн чачышып, көңдүн же чекенденин күлүн төгүшкөн.

Бул иш-чараларды жыландардын, курт-кумурскалардын жана башка мителердин жүрүш-турушуна жана биологиялык реакциясына негизделген, аларды сестентүү, коркутуу же алаксытуу сыяктуу салттуу ыкмалар деп эсептесек болот.

Март айы Кыргыз Республикасынын тоолуу аймактарында кыйла эле суук болгондуктан, түнкүсүн козулар тоңуп, суук тийип, натыйжада өлүп калышы да мүмкүн.

Март айынын ортосунда суур (Marmota) чээнден чыгат. Бул жаз келгендин бир белгиси. Эгерде тың болуп, оттоп кетсе жакшы, ал эми чээнден чыккан суур кайра ийинге кирсе, анда жут болот. Кар түшөт, шамал болот, көк чыкпай кечигет. Чээнде жаткан суурдун күндүн жылуу илебин, жаздын жытын сезе билүүсү бул табиятынан. Суурдун бул жүрүш-туруш реакциясы салттуу малчылыкта жагымдуу мезгил келгендиктин ориентири, белгиси катары колдонулган.

Жазында туулган козу уузга кенен тоюп, жаңы өсүмдүк менен оттукканына жакшы шарт түзүлүп, жай, күз мезгилдеринде эттенип, кышка толук даяр болуп калат. Өтө суукта туулган козу суукка урунат, ошондой эле ысыкта туулган козу кийин суука чыдамы жок болуп калган. Ошондуктан койлордун куутка кирчү мезгили кочкордун уруктандырууга, койдун урукту өстүрүүгө эң жагымдуу учуру катары каралып, козулар жаңы туулган күн аба ырайынын, мезгилдин шартынын эң туура келген күнү катары бааланган. Мындай жагымдуу учурду - койлордун кууту башталаар күндү аныктоо үчүн, мурунку жылдын жазында суурлардын чээнден чыккан күнүнөн, артка беш ай саналып белгиленген.

Кой тууганга аз калганда туздан өксүтпөй кенен беришкен, өксүсө козусу жүн жеп, жумуруна жүн топтолуп, ылаңга алып келет (Morbus bezoaris).

Жаңы туулган козуну энесинин уузуна жакшы тойгузуш керек, анткени уузга тойгон козу дени сак болуп, тез ирденет. Кой жаңы тууганда, желин үрпүнүн тешигинде нык катыган ууз тыгын болот. Бул тыгынды жаңы туулган козу эме электе, бир аз уузу менен кошо саап салышкан, антпесе бул тыгында жана анын тегерегинде топтолгон кирдин (микроорганизмдердин) таасиринде козунун карын-ичеги системасынын кызматы бузулуп, ичи өтөт. 
Эрте жазда жаңы эле кылтыйып чыгып келе жаткан өсүмдүктөрдү кышы бою ачыккан койлор чуркап жүрүп, терип оттошот. Бул койлордун көк кубалаганы.

Көк кубалоонун мааниси өтө чоң, себеби бул жерде тоют аз, ал эми кыймыл көп. Ошол эле учурда, жаш өсүмдүк койлордун ичин да өткөрөт. Көпкө чала тоют болгон, көк самаган кой, жаздын алгачкы күндөрү эле жаш өсүмдүктү тоё жесе, күптүү болуп калат да, ичеги-карынынын кызматы бузулуп, кийин жакшы эттене албайт. Ал эми башында бир аз ичи өтүп, ичеги-карды курттардан, мителерден тазаланып, андан соң аз-аздан тоюнган мал, кийин дене бою жазылып, жакшы эттенет. Бул, жаратылыштын өздүк тескөөсү.

Күн жакшы жылып, өсүмдүк жетишээрлик болуп калган маал - апрель айы. Апрель айында козулар үшүбөйт, тез телчигет жана бат отугат. Себеби өсүмдүктөр жакшы көтөрүлүп калгандыктан, энеси тоюнуп, сүтү жетиштүү жана козусуна жагымдуу болуп калат. Ошондой эле жер жылып, козуларга суук өтпөйт. Ал эми март айында тууган койлор көк кубалап, ичи өтүп, сүтүнүн сапаты начар болот.

Апрель айынын айрым бир күндөрүндө жаан жаап, катуу шамал болуп, аба ырайы суук болсо, жаңы тууган койлорду таңга маал саап салышкан. Себеби козулары тоё эмип алып, сыз жерге жатып калса, ичкен сүтү ирип, ичи өтүп жана суукка урунуп калышат. Ал эми чала тоют болгон козулар улам энесин кактап эмип, энеси менен чогуу басып, сыз жерге жатышпайт.

Жаздын ортосунда койлор бир аз тоюнуп, көк кубалабай калат. Ал эми жаздын аягында, же жайдын башында жаш өсүмдүктөрдүн жалбырагына, сабагына жетишээрлик тоюнган койлор ич май алып калышат. Ич май алган койлор кубаттуу келип, тоолуу жайыттарга чыкканда жакшы эттенишет.

Малдын сырын жакшы билген ата-энелерибиз, түркүн өсүмдүктүн гүлүн оттогон мал дарттан арылат жана мындай мал ылаңга чалдыкпайт, кыштан жеңил чыгат деп эсептешкен. Жайлоонун түркүн өсүмдүктөрүн оттогондон кийин малдын курттары көп түшөт, себеби кээ бир өсүмдүктөрдүн курт түшүргөн таасири бар экени белгилүҮ.

Кээ бир аймактарда малчылар жайлоого чыкканда койлорго улардын тезегин жедиргенге аракеттенишкен. Койлор улардын тезегин өсүмдүктөрдүн жытынан таап жешет. Улар бийик тоолордо оттоп, өтө сейрек кездешүүчү дары өсүмдүктөрдүн гүлдөрү менен дагы азыктанаары белгилүү. Улардын тезегинде жеген өсүмдүктөрүнүн жыты сакталып жана калдыктары калып, алыстан эле буркурап жыттанып турат. Улардын тезегин жеген койлор ылаңдан арылып, тез эле эттене баштаган.

Күз башталганда «жоодар катып баратыптыр, малдын ээгине сайылат» деп, жоодар көп өскөн жерлерден малды айдап кетишкен. Ошондой эле көк тикен, чычырканак өскөн жерлерге «малдын жүнүн, терисин бузуп, этине сайылып, малды жүдөтөт» деп, мал жайышкан эмес.

Кышкысын койлорду жайытка өтө эрте жайып чыкса, карда оттотсо, суу кечирсе, шыйрагы муздап, «кара шыйрак» болуп, жакшы оттой албайт («ак шыйрак» делип дагы жүрөт), арыктайт, ошондуктан койлорду короодон таңкы суук кеткенден кийин, кечирээк чыгарышкан.

Жайыты тескей болсо, шүүдүрүмдө койлорду короодон чыгарбаш керек, ошондой эле нымдуу, саздуу жерлерде кой жайганда туяктары ылаңга чалдыгат. Ал эми кургак жерлерде малды шүүдүрүмгө жайытка чыгарбаса, бат суусап кетет.

Ата-бабабыздан «Кырк күнү кык сакта, кырк күнү кыр сакта» деп айтылып келет. Бул сөз кыштын кырк күндүк чилдесинде койлор жаткан жери жылуу болуусу жана малга суук өтүп калбасы үчүн короого кургак кык чачып туруш керек дегенди түшүндүрсө, кырк күндүк жай чилдеде койлорду салкын, жел согуп турган тоонун кырларында карма дегенди түшүндүргөн.

Малга күнүгө майдаланган туз берилген. Туз бербесе мал топурак жеген, чычкактаган. Туздан кемибеген мал жакшы семирет, союлганда этинин даамы жакшы болот дешип, малды атайын шорлуу жерлерге айдап барып, «шорлотушкан», туз жалатышкан, ал эми айрым жерлерде атка же төөгө туз артып келип беришсе, ЫсыкКөлдүктөр малын «көлдөтөбүз» дешип, көлдүн суусун ичиришкен.

Кыргыз койлорунун башка койлордон бир айырмачылыгы - жайыттарды жана алардын өзгөчөлүктөрүн жакшы эстеп калып, уулуу өсүмдүктөр көп өскөн жайыттарды, жылаандын уюгу бар, кара курт көп, тикенектүү жана саздуу жерлерди айланып өтүшөт.

Малчыларга жайыттарда өскөн уу чөптөр да жакшы малым болгон. Өзгөчө уу коргошун көп өскөн жерлерге мал жайышкан эмес. Жакшы оттуу жерлерден уу чөптөрдү малчылар тамыры менен жулуп таштаган учурлар да көп болгон. Ошол эле учурда уу чөптөр жыш өскөн айрым бир жерлерди дарылыкка колдонулат деп сактап келишкен. 
Койлор алыстагы карышкырдын улуганын угуп эле үркүп тынч уктай алышкан эмес, анткени алар жаратылышынан коркок мал болот. Түнү бою үркүп, уктабай чыккан кой, эртеси жакшы оттой албай арыктай берген. Ушундан улам кыз-келиндердин түнү бою короо кайтарып, «бекбекей» айтып ырдап чыгышы шартка ылайык болгон. Жагылган оттон, кишилердин үнүнөн карышкыр коркуп келген эмес, ал эми койлор бул нерсеге тез эле кынык алып, өзүлөрүн тынч, жакшы сезген.

Жаңы туулган кулунду, музоону жана козуну сөзсүз түрдө сары май менен оозантышкан. Бул аракет жаш төлдүн «кара туңгагынан» (mekonion) жеңил бошошу максатында аткарылган.

Малдын ылаңдарын алдын алуунун жеке ии-чаралары жана ырым-жырымдары.

Бодонун көк көйнөгүндө (Pestis bovum), өлөтүндө (Pleuropneumonia contagiosa bovum) кыргыздар ылаңдаган малды таштап, сөзсүз түрдө кандайдыр бир өзөндөн ашып, көчүп кетишкен. Ылаң пайда болгонун кошуна айылдарга кабарлашкан.

Кара өпкө (Pleuropneumonia infectiosa caprarum) же күл ылаңы (Variola, кишиде - чечек) чыкканда дароо жайыт которушкан. Ал эми эчкинин кара өпкөсү пайда болгондо, отордогу бардык эчкилерди союп, ал эми кошуна айылдар малын алысыраак айдап кетишкен.

Жакын аралыкта айбандардын кутурмасы (Rabies) чыкса, бардык иттердин мурун кайкысын ысык темир менен күйгүзүшкөн (Aldashev 1989).

Мал шарп (Aphtae epizooticae) болбосун деп, сайдын баткагын кечирип өтүшкөн.

Боор мите ылаңын (Fasciolosis) алдын алууда чекендени жана адырашманды кеңири колдонушкан.

Кылчык жүндүү кыргыз койлорунун жүнү узун, бирок сейрегирээк болуп, чыбашы жок болгондуктан, кенелердин жашоосу үчүн ыңгайсыз. Ошондуктан кылчык жүндүү койлордун котуру (Acaroidosis) aз кездешкен.

Котурдан, жайыт кенелеринен (иксод кенелери), бит менен бүргөдөн алдын алуу үчүн малды чоң өзөндөрдү, агын сууларды кечиришкен, табигый жылуу сууларга салышкан, кой, эчкилерди кекирени (Acroptilon repens) аралатып айдашкан, котур менен ылаңдаган мал ээлери, малы менен айылдан алыс барып олтурукташкан.

Жылкы битин алдын алуу максатында кыргыздар бир-эки жаштагы тай-кунандарды «кылдап», жал-куйругун кыркышкан. Мындай кыркуу тай-кунандардын чычаңын биттен жана “бөкөн курттан” сактаган (Sargashkayev 2015).

Мал түйнөк (Monieziosis) болбосун деп айрым бир учурларда малды короодон кечирээк чыгарышып, бир аз ач карын калтырып, кекире, шыбак, эрмен (Artemisia), көбүргөн (Allium atrosanguineum) жыш өскөн жерлерге жайышкан. Бул күнү малдын ичи тегиз өтүп кетсе, «курту түшүп, ичеги-карды тазаланды» деп баалашкан. Ошондой эле дартка шектүү малды коктуга түшүрүп, бир нече күн бою ат кулак (Rumex confertus), бака жалбырак (Plantago Major L.) көп өскөн жерлерге жайышкан. Күзүндө кыштоого мал айдап келе жатышып, жол жээгинде жыш өскөн адырашманга (Peganum harmala) да мал жайып, дарты болсо арылат деп эсептешкен.

Жылкынын азуусунун капталына түбү жок кошумча тиш чыгып, тоют жей албай калгандыктан, жылкыны арыктаткан. Кыргыздар бул кошумча чыккан тиш жылкынын оттоосуна тоскоол болуп, ылаңдата турган ашыкча тиш экендигин байкашып «ууру тиш» деп аташкан. Ууру тиш кунан-быштыларда кездешет. Ууру тиштүү малдын жүнү түйдөктөшүп турат. Негизинен жылкынын ууру тишин ооздук эле кагып салат. Эл арасында жылкынын ууру тиштерин чагып, сууруп же жулуп ала турган адис кишилер болушкан. Алар жылкыны жыгып, буттарын байлап, оозун кемээчтеп ачып, табылгыдан жасалган, атайын башы ичкертилген, узуну бир карыш жыгач сапты ууру тишке такап, балка менен омура чаап, тишти алып салышкан же ууру тишти камчынын сабы менен уруп койсо түшүп калган.

Кунан-быштыларда кездешүүчү дагы бир табигый көрүнүш - бул жылкынын тишөөсү. Үч жашка толук толгон жылкынын маңдайкы сүт тиштери түшүп, ордуна жаңы тиштер өсүп жаткан мезгилде тишөө байкалып, тишеген жылкы толук кандуу оттой албай, чычкактап, арыктайт. Тишеген жылкыны кошумча тоюттандырышып, же убактылуу минбей оттуу жайыттарга агытып жиберишкен.

Кунан-быштылар жана туягы жука, же туягынын астындагы туранын чор эттери өсүп кеткен чоң аттар таштак жолдордон, тоо-таштардан бүжүндөп баса албай аксап ташыркашкан (Sargashkayev 2015).

Ташыркабасын үчүн аттарды темир такалар менен такалашкан. Атты такалоодон мурун туяктарын жибитүҮ максатында сууга же суулуу саздак жерге байлап коюшкан. Атты кермеге аса байлап, туяктын астындагы чор тура эттерин жакшылап кесип тазалап, туяктын така жата турган кырларын бычактын, сынтарачтын же дүрпүнүн жардамы менен, така тегиз жаткандай кылып тегиздеп, анан така урушкан. Таканын мыгы таканын 
ичиндеги сөөгүнө, турага тийгизбей кагылат. Мык тирүү тканга тийип калган болсо, ат биротоло майып болуп, аксап мингенге жарабай калышы мүмкүн.

Кыргыз жылкыларынын ичинен тубаса, такыр ташыркабаган, сом туяк, чыдамкай жылкылар көп кездешет. Мындай жылкылар такалоого муктаж болгон эмес.

«Бутуна жем түшүп кетет» дешип, жылкыларды жем жегенден кийин сугарышкан эмес. Жылкылардын туяктарынын ревматикалык сезгениши (pododermatitis reumaticas, laminitis reumatica) боюнча ветеринария илиминдеги маалыматтар бул иш-чаранын туура аткарылганынын далили. Анткени бул дарт денеси кызыган жылкылардын денесинин тез муздашынан келип чыгаары белгилүү (Zhurba ж.б. 2018).

\section{КОРУТУНДУ}

Макалада келтирилген мал ылаңдарын алдын алуу боюнча салттуу ыкмалар жана талкууда колдонулган илимий маалыматтар, бул багыттагы кыргыз элинин салттуу билимдери учурдагы ветеринария илиминин алгоритмдери жана тактикасы менен шайкеш келээрин тастыктайт.

\section{КЫЗЫКЧЫЛЫКТАРДЫН КАГЫЛЫШЫ}

Бул макалада кызыкчылыктардын кагылышы жок.

\section{АВТОРЛОРДУН САЛЫМЫ}

Бул макалада авторлор бирдей өлчөмдө салым кошушкан.

\section{ЫРААЗЫЧЫЛЫК}

Изилдөөлөр Кыргыз-Түрк "Манас" университети тарабынан каржыланган жана "Мурас Башаты" коомдук фонду көмөктөшкөн “Кыргыз элинин салттуу ветеринардык билимдерин изилдөө” (KTMÜ-BAP-2015.FBE.01) илимий долбоорунун жана Кыргыз Республикасынын Билим берүҮ жана илим министирлиги тарабынан каржыланган «Салттуу ветеринардык билимдерди жайыт малчылыгында колдонуу боюнча практикалык сунуштарды иштеп чыгуу» (№0007402) долбоорунун алкагында аткарылган. Көрсөткөн көмөгү үчүн ыраазычылык билдиребиз.

\section{КОЛДОНУЛГАН АДАБИЯТТАР}

Abramzon SM 1999. Kyrgyz zhana Kyrgyzstan tarykhy boyuncha tandalma emgekter. Kotorgon S. Mambetaliyev, D. Sulaymankulov, S. Makenov. B., «Kyrgyzstan SoroS» fondu, 896. (in Russian).

Aldashev AA 1989. Etapy razvitiya veterinarii v Kirgizii. Frunze, Ilim, 124. (in Russian).

Aliyev ND, Kuliyev KHG, Ibragimov GG 1970. Antimikrobnoye deystviye efirnykh masel nekotorykh vidov Heracleum L. iz Azerbaydzhana. Rastitel'nyye resursy. 7(1): 85-88. (in Russian).

Altymyshev A 1976. Lekarstvennyye bogatstva Kirgizii. Frunze, Kyrgyzstan. 351. (in Russian).

Apostolico I, Aliberti L, Caputo L, De Feo V, Fratianni F, Nazzaro F, Souza LF, Khadhr M 2016. Chemical Composition, Antibacterial and Phytotoxic Activities of Peganum harmala Seed Essential Oils from Five Different Localities in Northern Africa. Molecules. 21(9), E1235. DOI: 10.3390/molecules21091235.

Astulla A, Zaima K, Matsuno Y, Hirasawa Y, Ekasari W, Widyawaruyanti A, Zaini NC, Morita H 2008. Alkaloids from the seeds of Peganum harmala showing antiplasmodial and vasorelaxant activeties. J. Nat. Med. 62(4): 470-472.

Aytmatov MB, Alymbekov KA, Bayteleev EB zh.b. 2017. Kyrgyz elinin salttuu bilimderinin negizderi. Khrestomatiya. Bishkek, 304 (in Kyrgyz).

Bakanov T 1971. Narodnaya veterinariya v Kirgizii. Sel'skoye khozyaystvo Kirgizii. 12: 34-35. (in Russian).

Herraiz T, Guillén H, Arán VJ, Salgado A 2017. Identification, occurrence and activity of quinazoline alkaloids in Peganum harmala. Food. Chem. Toxicol. 103: 261-269. DOI: 10.1016/ j.fct.2017.03.010.

Karomatov ID 2014. Primeneniye garmaly obyknovennoy (dikoy ruty, mogil'nika) v drevney i sovremennoy meditsinskoy praktike: obzor. Traditsionnaya meditsina, 3(38): 22-27. (in Russian).

Li S, Cheng X, Wang C 2017. A review on traditional uses, phytochemistry, pharmacology, pharmacokinetics and toxicology of the genus Peganum. J. Ethnopharmacol. 203: 127-162. DOI: 10.1016/j.jep.2017.03.049.

Mammadova ZA 2015. Essential oils properties of Nepeta L. species in Azerbaijan flora. Global Journal of Biology, Agriculture \& Health Sciences (GJBAHS). Global Institute for Research \& Education, January-March. 32-37.

Mina CN, Farzaei MH, Gholamreza A 2015. Medicinal properties of Peganum harmala L. in traditional Iranian medicine and modern phytotherapy: a review. J. Tradit. Chin. Med. 35(1): 104-109.

Moloudizargari M, Mikaili P, Aghajanshakeri S, Asghari MH, Shayegh J 2013. Pharmacological and therapeutic effects of Peganum harmala and its main alkaloids. Pharmacogn. Rev. 7(14): 199-212. DOI: 10.4103/0973-7847.120524.

Nenaah G 2010. Antibacterial and antifungal activities of (beta)-carboline alkaloids of Peganum harmala (L) seeds and their combination effects. Fitoterapia. 14. 
Novikov OO, Pisarev DI, Zhilyakova YET, Trifonov VB 2014. Mozhzhevel'nik: fitokhimiya i farmakologiya roda Juniperus L. M.: Izd. RAMN, 178. (in Russian).

Raimbekov D 2010. Zhalpy epizootologiya. Bishkek, Kut-Ber. 392. (in Kyrgyz).

Sargashkayev EA 2015. Kyrgyzdardagy mal ylaydaryn daryloonun eldik salttary (XIX kylymdyn ayagy - KHKH kylymdyn bashy. Kyrgyzstandyn tyndygynyn materialdarynyn negizinde). Tarykh ilimderinin kandidaty okumushtuuluk darazhasyn izdenip aluu Ychyn zhazylgan dissertatsiyanyn avtoreferaty. B., 28. (in Kyrgyz).

Soliman AM, Abu-El-Zahab HS, Alswiai GA 2013. Efficacy evaluation of the protein isolated from Peganum harmala seeds as an antioxidant in liver of rats. Asian. Pac. J. Trop. Med. 6(4): 285-295.

Soltonoyev B 1993. (Kyzyl) Kyrgyz tarykhy: Tarykhyy ocherkter. Bishkek, 1-kitep (2008 b), 2-kitep. 224. (in Kyrgyz).

Tulobaev AZ 2001. Stanovleniye i razvitiye veterinarnogo obrazovaniya v Kyrgyzskoy Respublike. Sbornik trudov mezhvedomstvennoy prakt.-nauchnoy konferentsii. Kara-Balta. 23-32 (in Russian).

Tulobaev AZ, Niyazbekova ZN, Askarbek Gulnaz 2018. Znacheniye pastbishchnogo zhivotnovodstva i etnoveterinarii v Kyrgyzskoy Respublike. Vestnik KNAU. Bishkek, 2(47): 178-182 (in Russian).

Tulobaev AZ, Salykov RS 2016. Kyrgyzy. Narodnaya veterinariya. M., Nauka, 456-462. (Narody i kul'tury) (in Russian).

Tulobaev AZ, Salykov R, Askarbek Gulnaz, Niyazbekova ZN 2014. Kyrgyz elinin veterinariya boyuncha salttuu bilimderi. Vestnik KNAU. Bishkek, 1(30): 111--116 (in Kyrgyz).

Zhunushov AT 1991. Veterinarnaya sluzhba na putyakh perestroyki. B. Kyrgyzstan (in Russian).

Zhurba VA, Rukol' VM, Khodas VA 2018. Revmaticheskoye vospaleniye kopyt u loshadey. Nashe sel'skoye khozyaystvo. 14: 26-31 (in Russian). 